\title{
Community Driven Development in Slum Management in Covid-19 Era
}

\author{
Argyo Demartoto ${ }^{1}$, Akhmad Ramdhon ${ }^{2}$ \\ ${ }^{1,2}$ Department of Sociology, Universitas Sebelas Maret, Surakarta, Central Java, Indonesia
}

\begin{abstract}
Covid-19 pandemic spreads more widely in Indonesia. As a developing country with high population growth, urban areas in Indonesia are getting denser along with the high urbanization rate. Limited land in urban areas generates slums, for example, in Surakarta. The slum management phenomenon in Surakarta, Indonesia, is the object of this case study research using Community-driven development (CDD) theory. Data on public participation in slum environment arrangement and management in Surakarta was collected using in-depth interviews, focus group discussion, and observation on and documentation related to the phenomenon. The result of the research showed some stages of slum arrangement in Surakarta: planning using FGD method conducted by citizens and stakeholders; implementing slum arrangement and management through repairing irrigation channel, providing feasible sanitation facility, building public open space, and developing Liquid Waste Processing Installation, and reviewing and evaluating the implementation of slum arrangement and management in Surakarta. The environment cleanliness and health maintaining behaviour is important to be habituated in urban communities to suppress Covid-19 transmission rate.
\end{abstract}

\section{Background}

The broader spread of the coronavirus exerts a considerable effect on society's life. Covid-19 can be transmitted through a droplet of people infected with the virus and through objects surrounding the patients. Therefore, it is important for people to maintain selfcleanliness and the surrounding environment. People are appealed to wear a mask anytime they go out of home, to wash hands using soap and hand sanitiser periodically to prevent the virus from attaching to hand, because the hand is the human's most productive body part, and to do physical distancing. Healthy and clean-living behaviour is the point the people should consider to improve the quality of health in the pandemic era. In addition, people are also recommended to keep obeying the health protocol specified. Through healthy and clean-living behaviour, people can prevent and suppress the Covid-19 transmission rate in Indonesia.

The central government appeals to all areas throughout Indonesia, from urban to rural areas, to maintain self and environment cleanliness to keep health. Although many Covid19 confirmed cases are found in big cities, rural areas are possible to have equal high risk. 
A large number of Covid-19 positive cases in urban areas is caused by some factors, among others: people not obeying health protocol and unclean residence environment just like in the majority of urban kampungs (villages) with the dirty condition [1]. Surakarta, as a city with a dense population, encounters a similar problem.

Rapid population growth in an urban environment with limited land makes the provision of settlement not optimal, thereby generating slums just like in Semanggi, Pucangsawit, and Sangkrah. The population growth increases particularly along with the rapid urbanization rate. The consequences of emerging slums are a low-quality environment, low public health degree, and escalated social conflict between communities. The dirty living environment condition results in the high risk of being infected with diseases in the people, particularly in the Covid-19 pandemic era [2]. Therefore, sustainable cleanliness and health management are required to apply to slums in urban areas to suppress the Covid-19 positivity rate in Indonesia.

Community driven development (CDD) is an approach to the implementation of development by improving public initiative to participate actively as actor and manager (organizer) [3]. In this case, the people formerly become the target of change only are led to be the implementer of the entire community development process. CDD can be accomplished through the attempts of strengthening and funding community groups, facilitating people's access to information, improving the quality of the community environment by means of policy reform and new institutions approved collectively that become the rule to the people in bringing the collective objective into reality. This research aims to study the slum management system in Covid-19 in Surakarta, Indonesia.

\section{Method}

This qualitative research took place in the slum area Semanggi District; Surakarta, Indonesia, with a case study approach [4]. Corresponding to the objective of the research, the sampling technique used was purposive sampling [5]. Unit of Analysis consisted of key informants, including the head of Semanggi District; main informants including Semanggi people who live near in slum area. There are a group of people who live in slum areas, such as permanent residents, pedicab driver's groups, scavengers, and homeless people.

The author conducted the in-depth interview, observation, and focus group discussion with Semanggi people, Surakarta, to obtain primary data. Secondary data was obtained from the relevant document and, likewise, social media with the internet. The author also used source and research method triangulations to validate the data, while data analysis was conducted using an interactive model encompassing data reduction, data display, and conclusion drawing [6]. Data were analysed using Mathie and Cunningham's Communitydriven development (CDD) theory.

\section{Result}

The area becoming the main priority of slum management in Surakarta, Central Java is Semanggi, with a 76.03 hectare-wide slum area. The layout design corresponds to the Mayor's Decree Number: 413.21/38.3/1/2016 about the Assignment of Slum Housing and Settlement Environment Area Location. The Head of Kelurahan Semanggi stated that in the areas of RT 02, 04, and 05 Semanggi, Surakarta, most people come from low-income societies dwelling on the unliveable land.

The first stage taken is to plan the slum management by involving people (communities) in identifying problems in the area. Such agendas are accomplished through FGD between local citizens. In this plan, people determine social, economic, and environmental 
conditions and inventory the community-owned buildings. The government also provide socialization involving local people. A Head of Citizen Association (Rukun Warga) in Semanggi stated that FGD conducted with multi-stakeholder collaboration would find consensus from the citizens to recover the function of irrigation channel and feasible sanitation. He also said that people agree with the presence of compensation to the deconstruction of some citizens-owned buildings.

Surakarta government attempts to realize the liveable settlement for the society amid the high risk of coronavirus transmission today. The condition of formerly dirty settlements is considered as very worrying to the health condition of people living in the area, particularly children and elders. In implementing the slum management, the government gives grants with compensation and provides heavy equipment because local people agree to participate in the rearrangement of irrigation channels and feasible sanitation facilities.

Providing facilities needed by public space for the people in urban areas is very important to do. Those facilities are also developed based on public participation to fulfil their social needs. Then, people also attempt to improve the quality of the environment by constructing communal Liquid Waste Processing Installation.

Following the arrangement and management, Surakarta Government, along with related stakeholders, always conducts monitoring routinely and periodically. The monitoring activity is conducted by each of the parties, including the settlement community and the institution external to the society, i.e. government through its related service. A Semanggi citizen stated that the monitoring and evaluation process has also been approved by the people in the previous planning process.

\section{Discussion}

Government and people's attempt of managing the slums in Semanggi Surakarta is an important point to revitalize the character of responsible and environment-oriented human resources. Community is the most important element to rearrange and manage urban slums. Although it is these communities that have created slums and lived in the environment for a long time, they can be aware of solving the living environment problems later $[7,8]$.

CDD concept has a character corresponding to the objective of empowerment. The main characteristic of CDD, in addition to involving the people in planning management and implementing the project actively, is the emphasis on decision making and activity resource management in almost all stages of the program. The problems faced by urban areas are, among others, slums, poverty, unemployment and bad sanitation [9]. To solve the problems emerging, the government should be able to involve the people to build a clean and healthy environment, particularly in the Covid-19 pandemic situation, making the people at high risk of being infected with the disease.

If people do not make any change and manage the slums where they live immediately, they will get more adverse consequences [10]. Some factors trigger the transmission of Covid-19: the increased volume of water used for washing hands will increase the volume of liquid waste, and the volume of hospital waste will also increase, including toxic and hazardous waste, mask, SPE, tissue, and disinfectant. Building density in urban areas pays less attention to spatial and social aspects due to limited land on the one hand and economic and cultural problems on the other hand $[11,12]$.

The measures to be taken by the people to arrange slums amid the Covid-19 pandemic situation are, firstly, to arrange the settlement environment by remaining to implement health protocol firmly. Secondly, access to the village's gate should be equipped with handwashing facilities. Thirdly, adequate sanitation facilities are also important to provide because houses and water are desirable in this condition. Lastly, the optimization of green open space, formerly conceived as the city's lung and rainwater penetration, combined and 
harmonized with the development of building's function as the solution to many public facilities such as semi-open market and mosque with a broad open garden instead is healthier and has multifunction [13].

\section{Conclusion}

The higher the Covid-19 transmission rate in Indonesia, the higher is the people's need for paying attention to their self and environment cleanliness, as well as their health. Majority Covid-19 positive confirmed cases occur in urban areas. Some factors make the city at high risk of Covid-19 transmission: dense population, no reasonable distance between residents' houses, and no consciousness of maintaining the cleanliness of residence environment. Therefore, government collaborates with stakeholders and involves the people in slums in Surakarta to arrange and to manage the slums in order to avoid the incidence of diseases in pandemic situation. Through the management of living environment, people contribute to minimizing the risk of Covid-19 transmission in urban areas.

\section{References}

1. K. P. Wasdani, A. Prasad, The impossibility of social distancing among the urban poor: the case of an Indian slum in the times of COVID-19, The International Journal of Justice and Sustainability, (2020)

2. R. M. Buckley, Targeting the World's Slums as Fat Tails in the Distribution of COVID-19 Cases. J Urban Health. 97, 358-364 (2020)

3. A. Mathie, G. Cunningham, From clients to citizens: Asset-based Community Development as a strategy for community-driven development, Development in Practice, 13(5), 474-486 (2014)

4. R. K. Yin, Case Study Research and Applications Design and Methods $6^{\text {th }}$ Edition (Sage Publication Inc, Thousand Oaks, California, 2017)

5. R.A. Krueger, M.A. Casey, Focus Groups A Practical Guide for Applied Research $5^{\text {th }}$ Edition (Sage Publication Inc, Thousand Oaks California, 2015).

6. B.M. Miles, A.M. Huberman, J. Saldana, Qualitative Data Analysis: A Methods Sourcebook $3^{\text {rd }}$ Edition (Sage Publication Inc, Thousand Oaks, California, 2014)

7. A. Wilkinson, Local response in health emergencies: key considerations for addressing the COVID-19 pandemic in informal urban settlements, Environment \& Urbanization, 32(2), 503-522 (2020)

8. R.S. Pimenta. The risk of COVID-19 transmission in favelas and slums in Brazil. Public Health, 183, 42-43 (2020)

9. World Health Organisation and the United Nations Children Fund, 2020, Water, sanitation, hygiene, and waste management for COVID-19 virus, Interim guidance, 23 April 2020, WHO reference number: WHO/2019-nCoV/IPC_WASH/2020.3.

10. J. Corburn, D. Vlahov, B. Mberu, L. Riley, W. T. Caiaffa, S. F. Rashid, A. Ko, S. Patel, S. Jukur, E. M. Herrera, S. Jayasinghe, S. Agarwal, B. N. Yongsi, J. Weru, S. Ouma, K. Edmundo, T. Oni, H. Ayad, Slum Health: Arresting COVID-19 and Improving Well-Being in Urban Informal Settlements, J Urban Health, 97, 348-357 (2020)

11. S. Shirleyana, R. Y. Hawken, Sunindijo, City of Kampung: risk and resilience in the urban communities of Surabaya, Indonesia, International Journal of Building Pathology and Adaptation, 36(5), 543-568 (2018) 
12. L. von Seidlein, G. Alabaster, J. Deen, J. Knudsen, Crowding has consequences: Prevention and management of COVID-19 in informal urban settlements, Building and Environment, 188, 1-9 (2021)

13. A. Sharifi, A. R. K. Garmsir, The COVID-19 pandemic: Impacts on cities and major lessons for urban planning, design, and management, Science of the Total Environment, 749, 1-14 (2020) 